\title{
The Effects of Tenurial Change in Nineteenth-Century Latin America and New Zealand: A Search for Parallels and Origins
}

RICHARD P. BOAST

\section{Introduction}

As Mario Vargas Llosa has remarked in a recent essay, while Latin America is a projection of the Occident, it has also acquired a number of features peculiar to itself, which give it a distinctive character of its own: 'Sí, América Latina es una prolongación ultramarina de Occidente, que, desde la colonia, ha adquirido perfiles propios, los que, sin emanciparla del tronco común, le dan una personalidad diferenciada'. ${ }^{.}$Similarly, New Zealand, likewise an overseas projection of Western Europe, has also acquired its own distinctive personality, in part because of a history of engagement with an indigenous non-European culture, as is the case with many Latin American countries (in varying degrees).

In this paper I wish to focus on a so far little-noticed parallel between Latin America and New Zealand: the revolutionary changes in land tenure that took place in the nineteenth century. In both Latin America and in New Zealand these changes had enormous consequences for indigenous communities. ${ }^{2}$ While there have been a number of interesting books which compare developments in this area within the related jurisdictions of the common law world, there has not been, to my knowledge, any sustained discussion of parallels beyond this. ${ }^{3}$ There is one obvious reason for this. New Zealand and the Spanish American republics differ from each other not only culturally, historically, and in language, but also because they belong to different legal families: countries such as Brazil and Mexico belong to the civil law world - in fact they are the two of the largest civil law countries in the world. Latin American legal traditions and styles of legal scholarship derive from France, Spain and Italy. ${ }^{4}$ Common lawyers and civilians belong to distinct legal civilizations. On the whole, when New Zealand lawyers look to overseas parallels to legal developments at home they have tended to look within the common law world and not further afield.

The seventeenth-century political philosopher Thomas Harrington, who published his classic work Oceana in England in 1656, is known especially 
for his attempts to link patterns of land-holding with republican liberty. ${ }^{5}$ That there is some connection between tenure and political liberty and stability seems to be borne out by empirical experience, as, for instance, is suggested by the contrasting histories of two adjoining Central American countries, Costa Rica and Nicaragua. The first, a land of small family farms and rural prosperity, rather like a Central American version of New Zealand, also stands out in its own region for a long history of democratic stability and levels of literacy and health care that are equivalent to the developed world. Costa Rica is also blessed with a remarkable public ideology of democratic republican nationalism and a strong sense of exceptionalism. While it must be admitted that prominent Costa Rican historians are beginning to wonder whether their country's unique brand of political and economic exceptionalism, 'la excepcionalidad de Costa Rica' might now be under threat from the pressures of a globalized international economy, the contrast between these two countries remains very marked. ${ }^{6}$ Nicaragua, for much of its history a land of great estates and landless peons, has had an unhappy history marked by considerable instability, dictatorship and oppression. It remains one of the poorest countries in the western hemisphere. Yet ethnically Costa Rica and Nicaragua are very similar (whatever Costa Ricans and Nicaraguans themselves may say), both are small Central American countries lacking in mineral resources and heavy industry, and both have economies based on the export of coffee and other primary products. Many observers see differences in patterns of land-ownership as one of the key ingredients in understanding the contrasting fates of these two neighbouring Latin American republics. ${ }^{7}$ It seems from this example that patterns of tenure and land ownership have significant connections with national well-being in a broader sense.

My paper seeks to pursue these questions by means of a comparative discussion of an important aspect of the legal history of land tenure: the legal transformation of indigenous tenures in the nineteenth century. In nineteenthcentury New Zealand a substantial effort was made to convert lands held on indigenous customary tenures into modern and individualized forms of tenure recognizable in modern law. The vehicle for this change, a true tenurial revolution, was legislation of the colonial parliament, in particular the Native Lands Acts, but also the legislation relating to confiscation of land belonging to rebel Maori. The confiscation legislation, as I have argued elsewhere, was designed not only to take land from 'rebels' but also to remodel the tenure of land regranted to those deemed not to be in rebellion. ${ }^{8}$ The effects of this tenurial revolution in New Zealand have been dramatic, and transformatory. In New Zealand, however, this transformation took place in a society which totally lacked a powerful body of conservative opinion - there was no established Church, and no equivalent of a Tory 
party of landowners and bishops. A powerful, landed Conservative party such as those that existed in Colombia or Argentina did not exist. Nor was there a powerful class of large landowners and policies were implemented to ensure that one did not arise. The land acquired from Maori ended up mostly being granted to small settlers for family farms. In New Zealand - as in Costa Rica - an ideology stressing the benefits of close settlement and the family farm has played an important role in national life and has had important impacts on policy. The various ways in which this ideology worked its way through into land acquisition and land settlement policy was one of the themes of my 2008 book, Buying the Land, Selling the Land. ${ }^{9}$

In the nineteenth-century Spanish American republics, newly independent from Spain there was, as in New Zealand, a legal assault on indigenous lands held on customary tenures. This was accompanied by an attack on the extensive land-holdings of the Catholic Church. These lands included those belonging to the secular Church of bishoprics and parishes, and the extensive land-holdings of the regular orders such as the Dominicans, Franciscans and Augustinians - the Bourbon monarchy having already prohibited the Society of Jesus and expropriated their properties in the eighteenth century. In both the New Zealand and the Latin American case these equivalent processes of change were driven by liberal and modernizing elite groups within colonial society who had seized political control at the local level, and in both cases the process of 'reform', if it deserves the name, was embarked on by a mixture of motives in which a hope to benefit directly from the alienation of indigenous lands and an ideological belief in the value of modern tenures in unlocking opportunities for development and modernization were uppermost. Or, to put it more crudely, both greed and ideology played a role. Greed, alas, is a human constant in this fallen world. It is the ideological parallels which are the more interesting, and the more susceptible of inquiry by mere mortals. But to pursue matters further it is necessary to look more closely at our two parallels.

\section{Tenurial change in nineteenth-century New Zealand}

The New Zealand example can be described briefly. In New Zealand it was assumed that the indigenous people held title to the entire soil of the country - a major difference with Australia, where the opposite assumption prevailed - and thus before land could be allocated to settlers from the British Isles, the Native title had to be extinguished somehow. Until 1862 this was done by what were known pre-emptive purchases or deeds: the Crown simply bought land off Maori and then handed it over to the provincial governments for allocation. These purchases were often of very large areas, and by this means about two-thirds of the customary title was extinguished, including virtually the whole South Island, a few inconsequential areas aside, and 
parts of the North. But Maori still held most of their lands in the densest areas of settlement in such areas as the Waikato, Taranaki, Hawke's Bay and the Bay of Plenty.

In 1862 the first Native Lands Act was passed, which switched from pre-emptive purchase to an entirely different approach. Maori title was converted to a Crown-granted tenure, held by Maori as named individuals (i.e. not by tribes or sub-tribes: iwi and hapu); once so-held it could be alienated to private purchasers or the State. Maori alternatively could keep such land in their own possession and often did so: they were free to alienate it or use it as they chose. Just as with similar schemes in other parts of the world, the net effect, however, was rapid alienation. The Native Lands Acts also created a new type of land tenure: land that had always been held in customary ownership, but now held on a 'modern' and English-law tenure by named individuals. This category of land, now known as 'Maori freehold land', remains important in New Zealand, and accounts for about $12 \%$ of the North Island to this day. The principal agency for all this was a particular court, the Native Land Court, which heard cases about Maori land and issued judgements in rem as to who the true owners were. As the Maori Land Court, this Court, New Zealand's oldest specialist court, is still very much a going concern and remains important in the Maori world. The main transformations in New Zealand took place from circa 1865-1886: it was the 1865 Act which was pivotal, and the Court did not really begin dealing which large blocks on an intensive scale until 1866; from then on the process of investigation and alienation was very rapid.

\section{Latin American examples: Mexico, Guatemala, El Salvador and Colombia}

Turning to Latin America, we come at the outset to an obvious point of divergence: in New Zealand there is no parallel to the very lengthy Spanish colonial period, which in Mexico (New Spain), can be said to have lasted from 1521-1810, three hundred years of a vast and elaborate colonial edifice by which the religious, political and educational institutions of the mother country were transplanted to the New World. It is often forgotten in the Anglophone world that in 1800 the biggest city (by far) in North America was Mexico City - as it is today - and that the Universities in Mexico City and Lima are about a century older than Harvard. Learned works of theology were being published in Lima two hundred years before the American Revolution. Spanish territorial claims in the New World were founded not on categories familiar to Anglo-American legal historians - discovery, conquest, settlement - but rather on an elaborate legal edifice, deriving from the Papacy's claims to universal jurisdiction, based on the papal grants of 1493 made by Alexander VI to the Crown of Castile, las bulas alejandrinas 
as they are known, which were embodied and and modified by the Treaty of Tordesillas between the kingdoms of Castile and Portugal in 1494.

The Spanish colonial empire in the New World was a vast edifice with marked regional divergences and large gaps between law and policy, on the one hand, and colonial realities, on the other, and thus, it is important not to over-generalize. It was a patrimonial society of castes, hierarchies and competing jurisdictions: a Baroque world in every way, as Octavio Paz so eloquently describes it in his celebrated study of the life and times of Sor Juana de la Cruz. ${ }^{10}$ Paz points out that the Spanish empire was seen not as collection of colonies belonging to Spain, but rather a group of kingdoms - a group that included New Spain - owing allegiance to the Spanish Crown. New Spain 'era otro de los reinos sometidos a la corona, en teoría igual a los reinos de Castilla, Aragón, Navarra o León'..1 Some Mexican patriots followed this line of reasoning through to argue that, once the Spanish monarchy had been overthrown by France during the time of Napoleon, the Spanish colonies recovered their independence: there was no Crown to unite them. ${ }^{12}$

While it is true that the enslavement of indigenous peoples was forbidden by imperial law, the empire was also characterized by a wide range of oppressive and exploitative devices designed to extract surpluses from subject populations. The reality of exploitation and oppression has been documented in scores of detailed monographs. ${ }^{13}$ It would be a mistake, however, to imagine that independence from Spain brought an improvement in the condition of the indigenous peoples of the continent - indeed, quite the reverse seems to have often been the case. With the collapse of the colonial empire in the nineteenth century the liberal regimes that assumed power in the newly independent republics embarked on a process of making formerly protected lands available for private ownership, sale, and use as a security - just as liberal colonial politicians did in New Zealand at more or less the same time. I will consider here briefly the main developments in four countries, Mexico, Guatemala, El Salvador, and Colombia. I will briefly note also the variety of ways in which the indigenous past fits into the political ideologies of these countries.

Probably the largest, and certainly the best-known of these Latin American transformations, was that which took place in Mexico. Even before the outbreak of the wars of independence in Mexico, some prominent liberals and intellectuals in New Spain had advocated abolishing legal distinctions between Indians and other citizens and for the abolition of church and communal lands. One source for this may have been the Bourbon monarchy's attack on the Jesuits; the other was probably the religious, agrarian and economic legislation of the French revolution and the establishment of a strict separation between Church and State in the independent United States. It is 
clear, however, that Latin America developed a pattern of anti-clericalism of the French type, also characteristic of nineteenth-century Spanish politics, which was much more extreme and polarizing than anything that developed in the United States.

The main Mexican statutes, which built on on the earlier Ley Lerdo or Ley de Desamortizacion ${ }^{14}$ of 25 June 1856, which in turn drew on earlier repartitional laws in the Mexican states of Michoacan, Zacatecas and Guanajuato, were enacted in 1863, 1875, 1883, and 1894. The later statutes reflected the views of a group of highly placed technocrats within the Díaz regime after 1876, the so-called Científicos, followers of Comptean positivism and strong believers in economic liberalism. ${ }^{15}$ Church lands and communal Indian lands were seen as archaic relics of the Spanish colonial empire and as obstacles to modernization, and the period of the liberal 'reforms' associated with the governments of Benito Juárez and Porfirio Díaz saw huge losses of Indian lands to private ownership during a period of rapid economic expansion. ${ }^{16}$ In the twentieth century, an ideology of indigenismo has flourished in Mexico, which tends to mean an attempt to portray the nation as a mestizo country born out of an encounter between Spain and the indigenous civilizations that created the Mexico of today. Sometimes this goes so far as to see the Mexican revolution against Spain as in fact a recovery of independence and as the revival of the ancient Aztec state, a perspective which, however appealing in some ways, is perceived by Mexican intellectuals, such as Octavio Paz, as nothing short of ridiculous. Indigenismo has certainly not always translated into beneficial outcomes for Mexico's actual indigenous peoples of today, such as the Maya communities of Chiapas and Yucatan, who are just as poor and marginalized as indigenous communities in the United States and Canada.

Land and land tenure issues continue to be important in Mexican politics generally today, as shown by the controversy in Mexico over the ejidos, lands held by communities and usually leased to local people by the municipality. What has happened in Mexico most recently is a re-emergence of the old programmes and old arguments of the Liberals and the Cientificos of last century, although today the ideological fountainheads for the neoliberal line of thinking are the World Bank, FAO, and the Inter-American Development Bank. These institutions perceive 'land titling, the setting up of land registries, and market-led reforms as central instruments in the fight against poverty in Latin America'. ${ }^{17}$ However, whether the rural poverty that continues to blight the lives of so many Latin American people today, can be alleviated by such means remains to be seen. As the popular songs have it, many Latin Americans still spend their lives living in those 'casas de cartón' or 'barracaos de zinco'. ${ }^{18}$ Although some countries, notably Brazil, have scored impressive achievements in the last few decades in lifting people out of 
poverty, whether neo-liberal ideologies of land tenure have much to do with it is an important question. I would add that one result of New Zealand's own land tenure policies was that by the 1920s and 1930s a lot of Maori people were living in rural squalor in cardboard houses and tin shacks, or their equivalent, as well: it took the combined effects of the welfare state and the post-war economic boom to improve matters significantly.

Guatemala, to take another example, achieved independence from Spain in 1821. More polarized than Mexico, the country was and still is characterized by sharp divisions between its large indigenous population, mostly ethnically Maya and speaking various Maya languages, and Ladinos, Spanish-speaking, non-Indian Guatemalans. The Maya of the Guatemalan highlands, conquered by the Spaniards and their indigenous Mexican allies by Alvarado and other conquistadores from 1524-1540, continued during the colonial period to live in their traditional communities managing their communally-owned lands, protected by Spanish colonial law. In independent Guatemala, however, a political rhetoric developed during the nineteenth century whereby the culture and values of the Maya people became seen as antithetical to liberalism and economic progress. Maya groups tended to support the conservative dictator Rafael Carrera who defeated the Liberals in 1839 and established an authoritarian regime which lasted for twentysix years. In 1871 Liberal groups regained control of the new republic and embarked on a comprehensive programme of title individualization and related changes to labour and revenue law, principally in order to encourage foreign investment in the coffee industry. In 1877, the Rufino Barrios administration ended the colonial system of rent payments by municipalities and at the same time enacted legislation requiring all landowners to prove ownership by means of recognized legal titles. According to one historian, these steps led to a reduction of Indian communal lands by at least half by the early twentieth century. Those who benefited included coffee planters or 'ambitious Ladinos capitalizing on the general ignorance and political vulnerability of the Indian'. ${ }^{19}$ Communal lands have continued to decline during the twentieth century, although some Indian municipalities have managed to retain their lands to the present day. ${ }^{20}$ Collective tenures, as I understand the position, were not however abolished as such (as they were in El Salvador), but certainly liberal regimes were hostile to such tenures and took steps to reduce their extent. Land and land tenure issues in Guatemala are no less important than in Mexico, but in Guatemala have a different twist: in the latter country the real issue is the radically unequal distribution of land in the country, which creates significant social problems and imposes major pressures on the Maya peoples of the Guatemalan highlands.

Another Central American country which underwent a similar process of tenurial transformation in the nineteenth century was El Salvador, 
which followed a very similar trajectory to Guatemala. ${ }^{21}$ In El Salvador, today the most densely populated of the Central American republics, the main changes took place from 1879-1896, with the same objective of expanding the coffee industry. Following pressure from coffee growers, who wanted make lands held on collective tenures either by municipalities (tierras ejidales) or indigenous communities (tierras comunales), a series of laws were passed which began by requiring that collectively held hands be measured and surveyed off, then provided that municipalities allocate lands to those who wished to grow coffee, and which in 1881 went to the length of abolishing collective tenures completely, requiring communities to distribute full ownership of lands to those who were engaged in cultivation. This process of tenurial change in El Salvador has been analyzed fully by the historical geographer David Browning. ${ }^{22}$ Because Indian communities in El Salvador happened to live mostly in areas which were especially suitable for coffee growing - unlike Guatemala - one historian has judged that 'the Salvadoran land reform was more harmful and virulent to Indian communities than the Guatemalan version' ${ }^{23}$ El Salvador also stands out as having taken the unusual stance of claiming - until recently - that there are no indigenous people left in El Salvador: everyone was supposedly mestizo. Who is, and who is not 'Indian' (indio) in Central America, and the connections between ethnic and national identity are contested terrain - as in New Zealand, although New Zealand is a far less edgy place, to put it mildly, than Guatemala or El Salvador. ${ }^{24}$

As another example, Colombia also set aside and granted formal titles to the former indigenous community lands in the nineteenth centuries, a process which, as in Mexico, was perceived as a liberal and emancipatory step. ${ }^{25}$ In Colombia these areas are known as resguardos (protections, protected lands), which, during the Republican period, were 'properly titled Indian lands enjoying a limited amount of political autonomy'. ${ }^{26}$ However, Colombia is as unlike Central America as can be imagined and the political and ideological context is very different - it is a country where the nineteenthcentury distinction between Liberals and Conservatives, characteristic of nineteenth-century Spain and Mexico as well, has continued unabated into modern times and has become entrenched in modern politics. Colombia is not unstable but is a country dominated by electoral party politics, but those politics are polarized - some would say, have been rendered poisonous - to a remarkable degree. It is also known today for having remarkably progressive policies with respect to its richly diverse indigenous peoples.

\section{Revivals of collectivism in Mexico and the United States}

Latin America may be a region which shares with the United States and New Zealand a tradition of hostility to indigenous collective tenures, but it is also 
a region in which a counter-movement has flourished. This counter-current has been especially important in Mexico, but it also echoed strongly in the United States in the 1930s and 1940s at a time when New Deal liberals, including John Collier and Felix Cohen, dominated the formation of Federal Indian policy under Roosevelt. In the Mexico of President Lázaro Cárdenas, Manuel Gamio, Diego Rivera and Frida Kahlo this renewed interest in indigenous collectivism fused with Marxism, fashionable admiration for the USSR, and sympathy for the agrarian programmes of the beleaguered Spanish republic.

To American legal historians, John Collier is a key figure in the history of Federal Indian law, the chief architect of the Indian Reorganization Act 1934 (IRA) and the inspiration for a new era in Indian policy in the 1930s and 1940s. ${ }^{27}$ Wilcomb E. Washburn has written that 'Collier's work as commissioner of Indian affairs is probably the most impressive achievement in the field of applied anthropology that the discipline of anthropology can claim'. ${ }^{28}$ Collier was friendly with the Mexican archaeologist, indigenist and secular liberal reformer Manuel Gamio, who had himself received part of his training in anthropology in the United States. ${ }^{29}$ The two worked together on the Inter-American Indian Institute, established after a major international conference at Pátzuaro, Mexico, in 1940. Collier wrote that '[t]his hemisphere does not contain a broader-minded man or a spirit more devoted than Manuel Gamio'. ${ }^{30}$ Gamio and Collier were both 'indigenists' in the sense that they were personally committed to community life and to the values and ethics of indigenous peoples as a counterweight to what they perceived as the selfish individualism of the modern world. Indians not only had the right to their own cultures: those cultures embodied ethical ideas which were valuable in their own right. Collier had led the attack on the allotment system originally introduced into the reservations by the General Allotment (Dawes) Act of 1884. ${ }^{31}$ He founded the American Indian Defense Organization in 1923 and always opposed assimilation of the American Indians. In 1933 Roosevelt appointed Collier as Commissioner of Indian Affairs, and Collier and his officials immediately began work on the legislation enacted as the IRA the following year. The IRA was a milestone in American legal history and many of today's Indian governments were established under it.

Collier openly admired Lázaro Cárdenas, president of Mexico from 19341940 and still today Mexico's most revered post-revolutionary president. ${ }^{32}$ The fact that a prominent United States government official and reformer could openly admire and esteem a Mexican radical politician like Cárdenas, who nationalized the ownership, production and distribution of petroleum and who was responsible for the return of vast areas of government lands to the indigenous communes under the ejido system illustrates the liberal and idealistic temper of American government under Roosevelt. For reasons 
that need not be explored here, following World War II United States policy entered a period characterized by support of authoritarian regimes in Central America and the Caribbean, the battle lines being regrettably hardened by events in Guatemala and Cuba in the 1950s. It is not coincidental that, within the United States, Federal Indian policy in the early 1950s also sharply reversed direction. The Indian New Deal and the work of Collier and his senior officials, including Cohen, had always faced congressional hostility. Following attacks by Western politicians on alleged favouritism to Western Indians as well as personal attacks on Collier himself, Collier resigned in 1945 and Indian policy was later placed in the hands of Dillon Myer - who had supervised the relocation of Japanese-Americans during the War, Collier having been a prominent critic of Myer's methods. In 1950 Myer embarked on a controversial policy of termination of tribal status and the phase of New Deal idealism in Federal Indian policy came to an end, to the great personal disappointment of idealists and intellectuals such as Felix Cohen. ${ }^{33}$

In the 1930s, both Mexico and the United States pursued a similar antiassimilationist path in indigenous policy, a major policy reversal for both countries, driven in both countries by progressive 'indigenist' officials: principally Gamio in Mexico and Collier in the United States. As noted above, these two were friends who admired and respected one another. Collier always retained a hemispheric sense about indigenist policy, probably more than Cohen did. In the United States the main vehicle for new policies was the IRA; in Mexico it was the ejido programme. Both had in common a rejection of earlier liberal models of individualizing tenures - policies pursued in many countries, including New Zealand - and a return to automony and collectivist communal tenures. A repudiation of capitalistic individualism and a revalorization of communal, if not 'communist' tenures, places American and Mexican Indian policy of the day well on the left, exemplifying a kind of idealistic communalism which has had many antecedents in American and English radical history and which was to reemerge in the idealistic environment of the new state of Israel after 1948 with its kibbutz movement.

None of these heady ideas had any impact in New Zealand, which went right on individualizing customary tenures throughout the twentieth century until there was no land in Maori customary title left. There are a number of possible explanations for this difference, but to me the most obvious is that while nineteenth-century New Zealand, settled largely by politicized Anglo-Scottish liberals and politically aware rural people from southern England, was by no means cut off from the intellectual life of the day, this was not the case in the first half of the twentieth century. Twentieth-century 
developments in such fields as anthropology and jurisprudence passed New Zealand by until after the Second World War.

James Belich has argued that twentieth-century New Zealand in a sense re-colonized itself, economically and intellectually, in the twentieth century, only escaping from this self-imposed torpor in the 1970s ${ }^{34}$ This interpretation is borne out by Maori land policy, which remained astonishingly mediocre, conservative and unimaginative until the pivotal Maori Lands Amendment Act of 1974. This Act was the work of Matiu Rata, who was also responsible for the Treaty of Waitangi Act enacted the following year. In 1929, admittedly, a new era half-dawned to some extent in New Zealand when Apirana Ngata became Native Minister and was able to put in place a programme of Maori land development financed by the state, but this was not accompanied by any formal changes to the tenurial system or any attempt to reverse the individualizing tendencies of the Native Lands Acts. But in Mexico and the United States things were very different.

\section{Parallels and dissimilarities}

Mexico, Guatemala, El Salvador and Colombia are thus very different countries with quite different political cultures. But all four are alike in having witnessed very significant changes in land tenure and land ownership in the nineteenth century: the 'ownership' and 'tenurial' revolutions. And this is just as true of New Zealand. What does this reveal?

This paper is only introductory and my own thinking about the relationships between tenure, indigenous peoples, and national political ideologies is still evolving. Where exactly this leads is not yet clear to me, I have to admit, but some points can be made as a basis for further work and reflection. There are certainly some marked similarities between land tenure policies in Latin America and New Zealand, and this seems interesting and intriguing in itself, or so it seems to me at least. Direct influence can probably be ruled out. It is hard to imagine that the Rufino Barrios administration in Guatemala or the Cientificos of the Porfiriato had heard of New Zealand's Native Land Acts, or that Chief Judge Fenton or Sir Donald McLean knew anything about Latin America - except perhaps from what they might have gained from reading Prescott's best-selling nineteenth-century histories of the conquests of Mexico and Peru. What these parallels indicate, rather, is a common source or set of ideas which can only originate in Europe - a belief that land held by the church, or held under traditional collective tenures, is in effect 'dead' land, useless as a security and a brake on economic growth and political advancement. The Spanish term used for the process, especially with respect to Church lands, is 'desamortización', which implies a sense of 'freeing-up' or 'bringing back to life' perhaps. 
One pivotal key to nineteenth-century Latin American history is nineteenth-century Spanish history (just as in the twentieth century the political fall-out from the Spanish Civil War was of great importance in Latin America). While the agrarian legislation of revolutionary and Napoleonic France, which no doubt affected the policies and programmes of Liberals in nineteenth-century Spain, must be important, nevertheless this does not explain an almost identical approach to land and tenures in Britain, Ireland, the United States, Hawai'i - and in New Zealand. French ideas, whether revolutionary or Napoleonic, exerted little influence in Britain and her colonial offshoots. Britain nevertheless had a tradition of parliamentary enclosure, of general enclosure acts, and of legislative abolition of what remained of customary tenures in Ireland and the Highlands and Islands of Scotland. From this tradition the Native Lands Acts in New Zealand may be said to originate. Nonetheless, there is a clear convergence between countries as various as the United States, Guatemala and New Zealand which obviously derives from a common ideological source shared by all the European states and the colonies and former colonies. This remains to be rediscovered and understood before the entire evolution of the tenurial revolutions of the nineteenth century can be really understood (There may also be connections as well with the endless debates over agrarian reform in nineteenth-century Russia). A powerful ideology is clearly at work. But where did it come from? That is something I would like to find out.

The second general point is that it seems important to consider not only the process and ideology that driving legislative interference with ecclesiastical lands and with indigenous customary tenures, but also with the details of the process of reallocation. Title individualization leads, almost inevitably, to land loss. Who, however, are the beneficiaries, and are they the same everywhere? What political and ideological underpinnings are there, which impact on the process of alienation? In New Zealand, for example, the ideology of 'close settlement' - dense rural settlement, the 'small man' on the land - was very important. Even after the process of individualization and privatization that I have described, it was the State which was the major purchaser of Maori land, by a huge margin. The legal framework relating to Maori land tenures was but a part of a much larger legal framework relating to public lands, which was hostile to large estates and protective of the small settlers. New Zealand is not a country of large rural estates and landless rural labourers, but a country of family farms, close settlement, and a network of thriving and prosperous country towns. It is a country not of rural poverty, like so much of Latin America, but of rural wealth - like other parts of Latin America (Uruguay, south-eastern Brazil, Argentina, Costa Rica). It seems that the individualization and allotment of customary and church lands in Mexico and Guatemala was not to the 
benefit of small farmers and immigrants, but rather to the benefit of large landowners, especially the case in Mexico during the Porfiriato. Mexico then reversed these policies following the Revolution of 1910-1920, and large estates were broken up and regranted to rural communes, particularly during the presidency of Lázaro Cárdenas. Clearly then policies relating to allocation and distribution of titled and regranted former customary lands are pivotal. Allocation is as important as privatization and both must be understood before meaningful comparisons can be developed. A comparative perspective can particularly help elucidate the differences and similarities amongst a group of nineteenth-century countries and strive to grasp the varying consequences for wealth, poverty, and social development today.

1 Mario Vargas Llosa, 'Unidad y dispersión en América Latina', in Joseph J. Rishel and Suzanne Stratton-Pruitt, eds, Revelaciones: Las artes en América Latina, México D.F., 2007, xxiii-xxvii, at xxvi: ['Yes, Latin America is a projection of the Occident overseas, which, since the colonial period, has acquired features of its own, features which, without severing it from the common foundation, [nevertheless] give it a distinct personality'].

2 There are other parallels that can be explored. One is the importance of frontier treaties between colonial regimes and indigenous groups. Professor Abelardo Levaggi of the University of Buenos Aires has written a fascinating book arguing that despite Argentina's commitment to a strongly positivist legal culture in which 'treaties' between indigenous groups and the state were, strictly speaking, a juristic impossibility (in contrast with the United States), nevertheless such treaties, as a matter of actual practice, happened all the time: see Abelardo Levaggi, Paz en la frontera: fistoria de las relaciones diplomáticas con las comunidades en la Argentina (siglos XVI-XIX), Buenos Aires, 2000. I have argued elsewhere that the same is true of New Zealand in key respects: Boast, 'Recognising Multi-Textualism: Rethinking New Zealand's Legal History', Victoria University of Wellington Law Review (VUWLR), 37 (2006), pp.547-82.

3 See e.g. Stuart Banner, Possessing the Pacific: Land, Settler, and Indigenous People from Australia to Alaska, Cambridge, Massachusetts, and London, 2007 (Banner looks at Australia, New Zealand, Hawaii, California, British Columbia, Oregon, Washington, Fiji, Tonga, and Alaska).

4 For a fascinating and recent discussion analysis of the great legal traditions of the world, including the Civil law, Common law, Islamic Law and Talmudic traditions, see H. Patrick Glenn, Legal Traditions of the World, (4th ed), Oxford, 2010. The key differences between the civil law and common law traditions are usually understood by comparative lawyers to include the importance of Roman law (pivotal in the civil law, far less influential in the common law), the importance of legal codification in the nineteenth century in France, Spain, Germany and Italy (with Latin America following suit), the absence of a separate system of equity in the Civil law countries (civilians tend to be very puzzled by the common law's distinctions between legal and equitable obligations), and distinct attitudes towards precedent (the doctrine of stare decisis) and the relationship between courts and the legislature (the common law's emphasis on the role of the courts as law-making bodies in their own right is largely absent, at least theoretically, in the civil law world). Modes of trial procedure and the organization of the legal profession are also quite different. On the other hand, there are powerful 


\section{Journal of New Zealand Studies}

similarities between these two great legal families as well - for example legal historians today tend to stress that Roman law was not without influence in the common law. Also, as this paper is intended to show, local legislation is often as important as legal tradition: while Mexico and New Zealand belong to different legal traditions, the actual content of legislation in both countries has some interesting parallels.

5 For an analysis of Harrington's ideas regarding property ownership see J G A Pocock, The Machiavellian Moment: Florentine Political Thought and the Atlantic Republican Tradition, Princeton, 1975, pp.285-93.

6 See Iván Molina y Steven Palmer, Historia de Costa Rica, San José CR, 1997 (6a. reimpresión 2006), p.122:

Los costarricenses edificaron, en los intersticios dejados por los procesos políticos y económicos mundiales, una sociedad inusualmente estable e igualitaria. El desafío actual es más intenso que nunca antes y las opciones de maniobra son en extremo reducidas; pero quizá algunos sectores sociales encuentren vías originales para dar a la democracia nueva vida en un mundo decadente. ['In the interstices left by global economic and political processes, Costa Ricans constructed an unusually stable and egalitarian society. Today's challenge is more intense than ever before and there is very little room to manoeuvre; but perhaps some sectors of society will find new ways to give new life to democracy in a decadent world'].

7 Costa Rica's exceptionalism and the general links between land tenure and economic and political development were noted years ago by the prominent geographer of Latin America, Preston E. James. See James, Latin America, New York, 1950, p.651: 'The traditional large estate of Latin America is rare. Associated with this distinctive characteristic of land tenure and the widespread literacy is the notable attitude of equality among the people; there is no small group of landed aristocracy which dominates the social life, manipulates the politics with the support of an army, and collects the larger share of the benefits of the economy'. This represents a strong contrast with countries like Guatemala and El Salvador. More recent comparative accounts include Consuelo Cruz's Political Culture and Institutional Development in Costa Rica and Nicaragua, Cambridge, 2005, a very sophisticated discussion of the relationship between political culture and democracy in these two radically different neighbouring countries, and Jeffery M. Paige's Coffee and Power: Revolution and the Rise of Democracy in Central America, Harvard, 1997, which focuses on ideologies. Robert G. Williams' States and Social Evolution: Coffee and the Rise of National Governments in Central America, Chapel Hill and London, 1994, examines the varying parts played by governments in key areas such as land tenure and labour control - see especially pp.98-103, which summarize the roles played by governments in the area of land tenure in the various Central American countries).

8 Richard P. Boast, 'An Expensive Mistake: Law, Courts and Confiscation on the New Zealand Colonial Frontier', in R.P. Boast and R.S. Hill, eds, Raupatu: The Confiscation of Maori Land, Wellington, 2009, pp.145-68.

9 Boast, Buying the Land, Selling the Land: Governments and Maori Land in the North Island 1865-1921, Wellington, 2008. See also two key articles by Tom Brooking, 'Busting Up the Greatest Estate of All: Liberal Maori Land Policy, 1891-1911', New Zealand Journal of History (NZJH), 26 (1992), p.78; and 'Use it or Lose it: Unravelling the Land Debate in Late Nineteenth-Century New Zealand', New Zealand Journal of History (NZJH), 30 (1996), p.141.

10 See Octavio Paz, Sor Juana de la Cruz: las trampas de la fe, México, 1982, p.66. Octavio $\mathrm{Paz}$ in fact likens colonial New Spain (Mexico) to a kind of fortress, built around the 


\section{Effects of Tenurial Change}

institutions of the Viceroy's Court, the town council and the cathedral, flanked by the monastic convent, the university and the military fort, "but the convent and the university are likewise fortresses: they defended New Spain not from pirates or nomadic Indians but rather from the passing of time' ('[p]ero el convento y la universidad también eran fortalezas: no defendían a la Nueva España de los piratas y de los nómadas sino del tiempo'). New Spain 'was not built to change but rather to endure' ('Nueva España no estaba hecha para cambiar sino para durar').

11 Paz: '[It] was another of the kingdoms subject to the Crown, theoretically equal to Castile, Aragon, Navarre or Leon'.

12 Paz, p.31.

13 Only some representative books out of a rich and colossal literature can be cited. For some key regional and local studies, see Luis F. Calero, Chiefdoms under Siege: Spain's Rule and Native Adaptation in the Southern Colombian Andes, 1535-1700, Albuquerque, 1997; Laura Caso Barrera, Caminos en la selva: Migración, comercio y resistencia: Mayas yucatecos y itzaes, siglos XVII-XIX, México, 2002; Nancy M. Farriss, Maya Society under Colonial Rule: The Collective Enterprise of Survival, Princeton, 1984 (Yucatan); Ramon A. Gutiérrez, When Jesus Came, the Corn Mothers Went Away: Marriage, Sexuality, and Power in New Mexico, 1500-1846, Stanford, 1991 (New Mexico); W George Lovell, Conquest and Survival in Colonial Guatemala, Montreal, 1992 (Guatemalan highlands); Severo Martínez Peláez, Susan M. Neve (trans) and W. George Lovell (trans), La patria del criollo, Durham, 2009; Karen Spalding, Huarochirí: An Andean Society under Inca and Spanish Rule, Stanford, 1984 (Peruvian Andes); Steve J. Stern, Peru's Indian Peoples and the Challenge of Spanish Conquest: Huamanga to 1640, (2nd ed), Madison, 1993 (Peruvian Andes); Jan de Voz, La paz de Dios y del Rey: La conquista de la selva Lacandona, 1980 (Chiapas). This list could be prolonged substantially in English and more or less indefinitely in Spanish. Much of the more recent work is concerned to show that indigenous peoples of the Americas were not simply merely passive victims, but continued to be active makers of their own history. It is important to emphasize that by no means do all of these writers see the process of Spanish colonialism as simply or only a narrative of oppression and exploitation. Some other writers go out of their way to stress the more positive aspects of the colonial encounter. For a recent account which stresses convivencia (roughly, 'getting along') on the frontier, see John Kessell, Pueblos, Spaniards and the Kingdom of New Mexico, Norman, 2008.

14 This statute was named after the Mexican Liberal politician Miguel Lerdo de Tejada. The principal target of this statute was the vast endowed lands held by the Church. Much of this land was worked by peasant tenant farmers. One consequence of the law was that many of the endowed Church lands came into the hands of wealthy ranchers and owners of haciendas, leading in turn to far worse conditions for the rural peasantry. For a useful introduction to Mexican legal history in English see Stephen Zamora et al, Mexican Law, Oxford, 2004, pp.1-42; for full accounts see G. Margadant, Introducción a la historia del derecho mexicano, (8th ed), Mexico D.F., 1988; O. Cruz Barney, Historia del derecho mexicano, Mexico D.F., 1999.

15 The 'Positivist' philosophy of Auguste Comte, not to be confused with the jurisprudential theory of legal positivism, was never very influential in the Anglo-Saxon world, but was enormously significant in key Latin American countries such as Mexico and Brazil in the nineteenth and early twentieth centuries. Positivism, which sees humanity as progressing away from religious superstition towards rationalism and modernity, was not necessarily antithetical to indigenous interests. Many Brazilian supporters of Indian rights in the early twentieth century such as the famous explorer and ethnographer Candido Rondon, and political intellectuals such as Silvio de Almeida and Luis Horta Barboza were dedicated 


\section{Journal of New Zealand Studies}

Positivists. See generally John Hemming, Die if You Must: Brazilian Indians in the Twentieth Century, 2003, pp.1-23. The Positivist slogan, 'order and progress' (ordem e progreso) is on the Brazilian flag. On positivism in Brazil see also Todd A. Diacon, Stringing together a Nation: Cândido Mariana da Silva Rondon and the Construction of Modern Brazil, 1906-1930, 2004. Positivism was not entirely without influence in Britain (and perhaps, therefore, in British colonies): the reformer Charles Booth regarded himself as a positivist and it was an important strand in Fabianism: see Gertrude Himmelfarb, Poverty and Compassion: The Moral Imagination of the Late Victorians, New York, 1991, pp.82-85; 356-8. Its formal impact in New Zealand seems to have been slight but probably many key architects of Maori land policy such as Donald McLean, Francis Dart Fenton and John Ballance would have shared similar ideas.

16 There is a vast literature on land policies and the assault on communal lands in later nineteenth-century Mexico and Central America, most of it in Spanish. For an introductory discussion and a guide to further reading see Murdo J. McLeod, 'Mesoamerica since the Spanish Invasion: An overview', in Richard Adams and Murdo MacLeod, eds, The Cambridge History of the Native Peoples of the Americas, (Mesoamerica), Cambridge and New York, 2000, II, pp.1-43.

17 Monique Nuitjen, 'Family Property and the Limits of Intervention: The Article 27 Reforms and the PROCEDE Programme in Mexico', Development and Change (DC), 34, 3 (2003), pp.475-97; quote on p.476.

18 Cardboard houses (Sp.) and tin shacks (Port,). Both these are popular songs in Spanish America and Brazil.

19 W. George Lovell, Conquest and Survival in Colonial Guatemala, Montreal, 1992, p.33.

20 For developments in nineteenth- and twentieth-century Guatemala some key studies are Ricardo Falla, Quiché Rebelde, Guatemala City, 2000; Greg Grandin, The Blood of Guatemala: A History of Race and Nation, Durham N.C., 2000; Victor Montejo, Maya Intellectual Renassiance, Austin, 2005; W. George Lovell, A Beauty that Hurts: Life and Death in Guatemala, (2nd revised edition), 2010; Severo Martínez Peláez, La patria del criollo, Durham and London, 2009 [1970]. In the Guatemalan highlands the Ladinodominated military governments instituted a reign of terror against the highland Maya after 1978. Entire communities were massacred and many Maya people were forced to flee to Mexico and the USA, although, as noted, the Guatemalan situation was not simply a Ladino-indigenous collision: not all Maya groups opposed the government, and some of the victims of the period (referred to in Guatemala as la violencia) were Ladino. Nevertheless a number of Maya ethnic groups and many communities suffered appallingly. The events of la violencia have been investigated comprehensively by a special truth commission established after the Oslo Accords of 23 June 1994, the Comisión para el Esclarecimiento Histórico (CEH), which produced a major report (Guatemala: Memoria del silencio) in 1999. This report also contains a thorough analysis of the historical background to the violencia. It will take more than reports of this kind to decisively change things in Guatemala in my view.

21 For a comparative analysis of the varying consequences of the nineteenth-century coffee boom on the Central American republics, see Roger G. Williams, States and Social Evolution: Coffee and the Rise of National Governments in Central America, Chapel Hill and London, 1994. Chapter three of this book deals specifically with land tenure reform in the nineteenth century.

22 See David Browning, El Salvador: Landscape and Society, Oxford, 1971, pp.144-221. For a different historical interpretation however, see Aldo A. Lauria-Santiago, An 


\section{Effects of Tenurial Change}

Agrarian Republic: Commerical Agriculture and the Politics of Peasant Communities in El Salvador, 1823-1914, Pittsburgh, 1999.

23 Williams, p.76.

24 See generally Virginia Tilley, Seeing Indians: A Study of Race, Nation and Power in El Salvador, Albuquerque, 2005. El Salvador's indigenous ethnic population was not in fact Maya - as in Guatemala - but was made up of a mosaic of groups, of which the dominant group in western El Salvador was (and is) the 'Pipil' or Nahua, whose language is more or less the same as that of the Nahua peoples of central Mexico. In the eastern part of the country the main group is the Lenca, who seem to be related to the Chibchan peoples of Colombia.

25 See Fernando Díaz Díaz, 'Estado, Iglesia y desamortización', in Nueva Historia de Colombia (NHC), Bogotá, 2 (1989), pp.197-222.

26 Luis F. Calero, Chiefdoms under Siege: Spain's Rule and Native Adaptation in the Southern Colombian Andes, 1535-1700, Albuquerque, 1997, p.132.

27 On Collier see Lawrence Kelly, The Assault on Assimilation: John Collier and the Origins of Indian Policy Reform, Albuquerque, 1983; Kenneth R. Philp, John Collier's Crusade for Indian Reform, Tucson, 1977; E.A. Schwartz, 'Red Atlantis Revisited: Community and Culture in the Writings of John Collier', American Indian Quarterly (AIQ), 18 (1994), p.507. Collier began his career helping to organize immigrant workers in New York and was a committed New Dealer.

28 Wilcomb E. Washburn, 'A Fifty-Year Perspective on the Indian Reorganization Act', American Anthropologist (AA), New Series, 86 (1984), pp.279-89, at p.287.

29 Gamio is listed in the acknowledgments to John Collier's Indians of the Americas, Washington DC, 1947 (along with Felix Cohen, Nathan Margold, Harold Ickes and others). Gamio is famous in Mexico as the excavator and restorer of the ancient city of Teotihuacan and as a public intellectual and supporter of the movement known as indigenismo ('indigenous-ism', or 'Indianism'). On Gamio, see David Brading 'Manuel Gamio and Official Indigenismo in Mexico' Bulletin of Latin American Research (BLAR), 7 (1988), p.75; Lucinda Gutiérrez and Gabrielo Pardo, Descubridores del Pasado en Mesoamérica, México D F, 2001; Benjamin Keen The Aztec Image in Western Thought, New Brunswick, 1971, pp.470-71; Miguel León-Portilla 'Historia de la Arqueología en México: La Época de la Revolución', Arqueología Mexicana, 10, 56 (2002), p.10.

30 Cited in Collier, Indians of the Americas, p.175. Collier also admired the great Brazilian Indianist and reformer Candido Rondon.

31 General Allotment Act 25 USC § 331-354 (Dawes Act).

32 See Collier, p.96-97:

New revolutionary energy was the need. New passion, new vision, new administrative will. Lázaro Cárdenas supplied them. He became President at the end of 1934. In the six following years he established the agrarian revolution. He did very much besides. He established, once and for all, Mexico's national dominion over its natural resources, including oil. Working with the intellectually subtle, the brilliant, audacious Vicente Lombardo Toledano, he built organized labor into unity and power. Through millions - actually millions - of personal, face-to-face contacts with the Indians in every Mexican state, he built confidence and power into them. In 1940, though overwhelmingly the people's and the nation's choice, he refused to violate the constitutional clause against presidential self-succession; and he refused, and refuses still, to seek to dominate his successors from behind the scenes.

There has been no greater leader of any people in this age than Cárdenas; perhaps there has been none whose heart has been so rich and pure. Future time 


\section{Journal of New Zealand Studies}

will possibly measure his achievement on behalf of the Indians as second only to that of Las Casas.

33 See Lawrence G. Kelly 'United States Indian Policies, 1900-1980' and Philleo Nash, 'Twentieth-Century United States Government Agencies', in Handbook of North American Indians: Vol 4: History of Indian-White Relations, Washington, 1988, pp.66; 264. See also Felix S Cohen, 'The Erosion of Indian Rights, 1950-1953: A Case Study in Bureaucracy' Yale Law Journal (YLJ), 62 (1952-1953), p.348. Most of Cohen's stinging criticism is aimed directly at Commissioner Myer.

34 This is a thesis that Belich develops in his Paradise Reforged: A History of the New Zealanders from the 1880s to the Year 2000, Auckland, 2001. 